\title{
Experimental ulcerative herpetic keratitis. II. Influence of topical corticosteroid in immunised rabbits
}

\author{
C. A. CARTER, ${ }^{1}$ D. L. EASTY, ${ }^{2}$ AND S. R. WALKER \\ ${ }^{1}$ Department of Surgery, Medical School, University of Bristol; ${ }^{2}$ Bristol Eye Hospital, Lower Maudlin Street, \\ Bristol; and the ${ }^{3}$ Medical Division, Glaxo Group Research Ltd., Greenford, Middlesex
}

SUMMARY Since the great majority of patients possess immune responses to herpes simplex virus (HSV), the influence of a topical anti-inflammatory corticosteroid $(0 \cdot 1 \%$ clobetasone butyrate) on ulcerative herpetic keratitis was studied in rabbits with a previous HSV skin infection (immunised) and compared with that in normal rabbits. Corticosteroid treatment had a much greater ulcerationexacerbating effect in immunised than in normal animals. On day 7 the mean area of ulceration in immunised rabbits was 3 times greater in treated eyes. $0.01 \%$ clobetasone butyrate treatment had less effect on immunised rabbits; $0.001 \%$ had no effect. It is concluded that the immunised rabbit provides a useful experimental model for studying the relationship between concentration of topical anti-inflammatory agents and enhancement of herpetic ulceration.

It is known that the administration of antiinflammatory corticosteroids in ulcerative herpetic keratitis can result in severe exacerbation of disease with the development of geographic or amoeboid ulcers and an increase in the incidence of subsequent complications. ${ }^{12}$

Similar aggravation of herpetic corneal ulceration has been demonstrated in rabbits treated with drugs of this group. ${ }^{3-6}$ These studies cmployed normal rabbits which had had no previous contact with herpes simplex virus (HSV), while by contrast the majority of the human population have immune responses to the virus. Since a major effect of corticosteroids is to inhibit immune reactions, ${ }^{7}$ the use of rabbits with a previous HSV skin infection ('immunised'8) should more closely represent the clinical disease.

The aims of this investigation were to study the effect of a topically administered corticosteroid on ulcerative herpetic keratitis in normal and in immunised rabbits, and to examine the relationship between corticosteroid concentration and degree of enhancement of ulceration. Clobetasone butyrate was used because it is effective in various ocular inflammatory conditions and produces relatively little rise in

Correspondence to Miss C. A. Carter, Bristol Eye Hospital, Lower Maudlin Street, Bristol BS1 2LX. intraocular pressure in susceptible subjects. ${ }^{910}$

\section{Material and methods}

The details of virus and rabbits used, and the methods of immunisation of rabbits, corneal inoculation of virus, and assessment of corneal disease have been described. ${ }^{8}$ The ranges of virus concentration used were 0.4 to $26.1 \times 10^{5}$ $\mathrm{PFU} / \mathrm{ml}$ for normal and 3.9 to $250.0 \times 10^{5}$ $\mathrm{PFU} / \mathrm{ml}$ for immunised animals (PFU = plaqueforming units).

Clobetasone butyrate or placebo treatment was given 5 times daily at $1 \frac{1}{2}$ hour intervals, beginning on the day before corneal inoculation of virus. One eye of each rabbit received clobetasone butyrate and the other placebo, and the allocation of treatment was unknown to the observer. The standard concentration of the preparation was $0.1 \%$, and the vehicle was used as placebo and diluent. Experiments were continued until the extent of corneal ulceration became severe, or the placebo-treated eye had recovered from ulcerative disease.

The effects of $0.1 \%$ clobetasone butyrate on normal and immunised rabbits (4 animals in each group) were compared. The effects of $0.01 \%$ and $0.001 \%$ clobetasone butyrate were studied in immunised rabbits only $(5$ animals in each group). 


\section{Results}

EFFECT OF $0 \cdot 1 \%$ CLOBETASONE BUTYRATE IN NORMAL AND IN IMMUNISED RABBITS

The corneal infectious dose for $50 \%$ of inoculations $\left(\mathrm{CID}_{50}\right)$ measured at 2 days after infection revealed no difference between placebo- and clobetasone-butyrate-treated eyes, either in normal or in immunised rabbits (Table 1, Fig. 1).

In normal rabbits ulcerative disease showed a tendency towards increased severity in the corticosteroid-treated eyes on day 7 , the mean

Table 1 Mean $C I D_{50}$ values in placebo- and clobetasone-butyrate-treated corneas of the 4 groups of rabbits

\begin{tabular}{|c|c|c|c|c|}
\hline \multirow{2}{*}{ Rabbits } & \multicolumn{2}{|c|}{ Treatment } & \multicolumn{2}{|c|}{$C I D_{50}\left(P F U / m l \times 10^{5}\right.$} \\
\hline & Control & Experimental & Control & Experimental \\
\hline $\begin{array}{l}\text { Normal } \\
\text { Immunised } \\
\text { Immunised } \\
\text { Immunised }\end{array}$ & $\begin{array}{l}\text { Placebo } \\
\text { Placebo } \\
\text { Placebo } \\
\text { Placebo }\end{array}$ & $\begin{array}{ll}0.1 \% & \text { CB } \\
0.1 \% & \text { CB } \\
0.01 \% & \text { CB } \\
0.001 \% & \text { CB }\end{array}$ & $\begin{array}{r}9 \cdot 9 \\
104 \cdot 2 \\
94 \cdot 1 \\
97 \cdot 5\end{array}$ & $\begin{array}{r}5 \cdot 1 \\
141 \cdot 3 \\
104 \cdot 2 \\
147 \cdot 7\end{array}$ \\
\hline
\end{tabular}

$\mathrm{CB}=$ clobetasone butyrate.

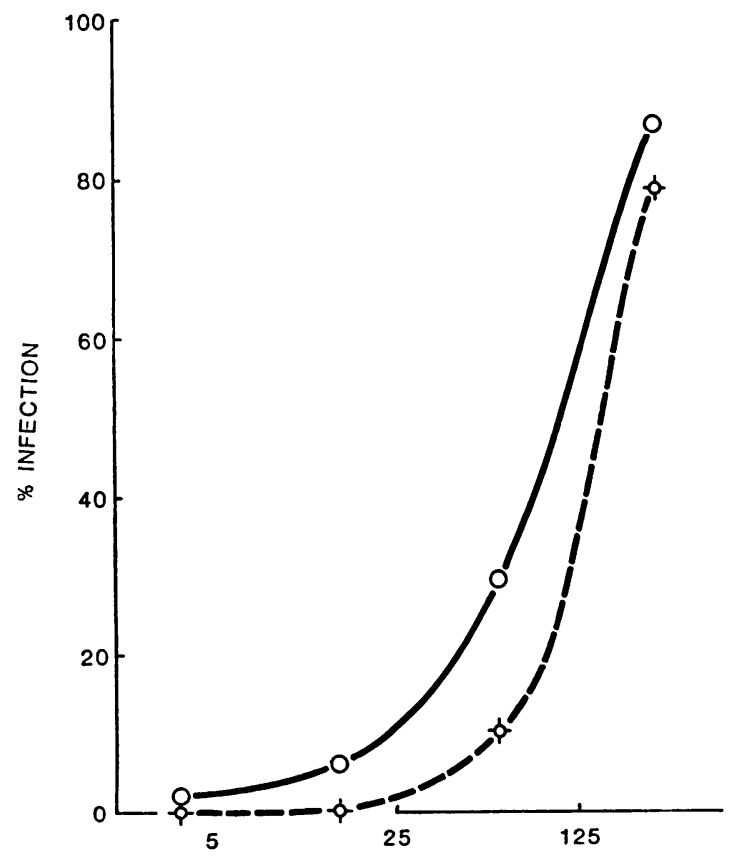

VIRUS CONCENTRATION (pfu/ml $\left.\times 10^{5}\right)$

Fig. 1 Virus titration in placebo- (-) and $0.1 \%$ clobetasone-butyrate-treated (- . - c) corneae in immunised rabbits.

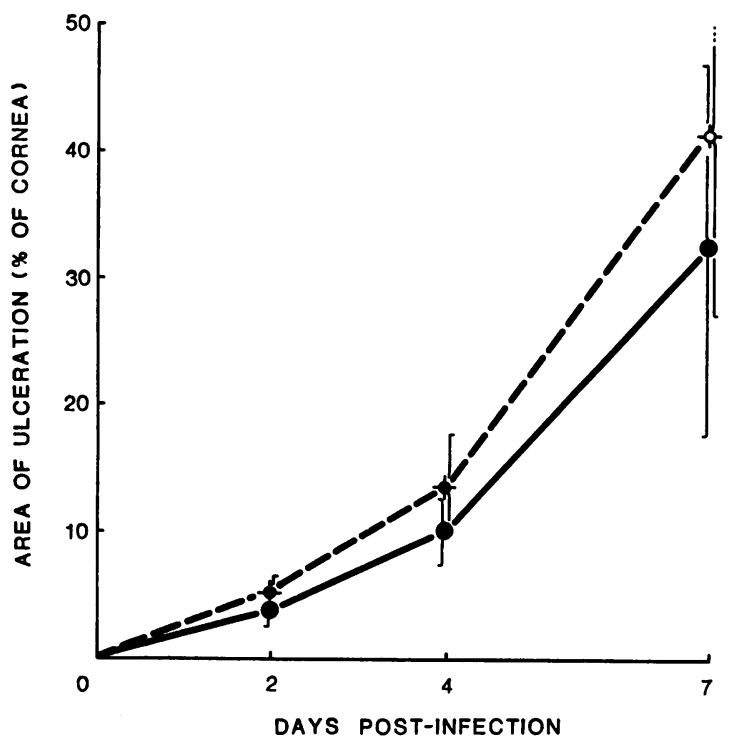

Fig. 2 Progress of ulcerative disease in placebo(-) and $0 \cdot 1 \%$ clobetasone-butyrate-treated (-..-) corneas: normal rabbits (mean area of corneal ulceration $\pm S E$ ) Range of virus concentrations inoculated: 0.4 to $26 \cdot 1 \times 10^{5} \mathrm{PFU} / \mathrm{ml}$.

areas of ulceration at that time being $32 \pm 15 \%$ (SE) of the cornea in placebo- and $41 \pm 14 \%$ in clobetasone-butyrate-treated eyes (Fig. 2).

In immunised rabbits a large difference between placebo and corticosteroid-treated eyes was observed. An increase in area of ulceration in clobetasone-butyrate-treated corneas was first seen on day 4 , and a very marked difference was found on day 7 , when the mean areas of ulceration were $6 \pm 5 \%$ of the cornea in placeboand $23 \pm 9 \%$ in clobetasone-butyrate-treated eyes. Pooled data from 18 eyes showed a statistically significant increase in areas of ulceration in eyes treated with $0.1 \%$ clobetasone butyrate ( $p<0.025$ : rank sum test). At this stage the healing phase of ulcerative disease had already begun in the placebo-treated eyes, while the area of ulceration in corticosteroid-treated corneas was at least that found on day 4. The form of the ulcers was largely geographic, with relatively regular margins. Two animals had large central epithelial defects, where the relative importance of viral infection and self-inflicted abrasive loss of diseased epithelium was not clear. Between days 7 and 9 a reduction in area of ulceration occurred in both placebo- and corticosteroidtreated eyes (Fig. 3). 


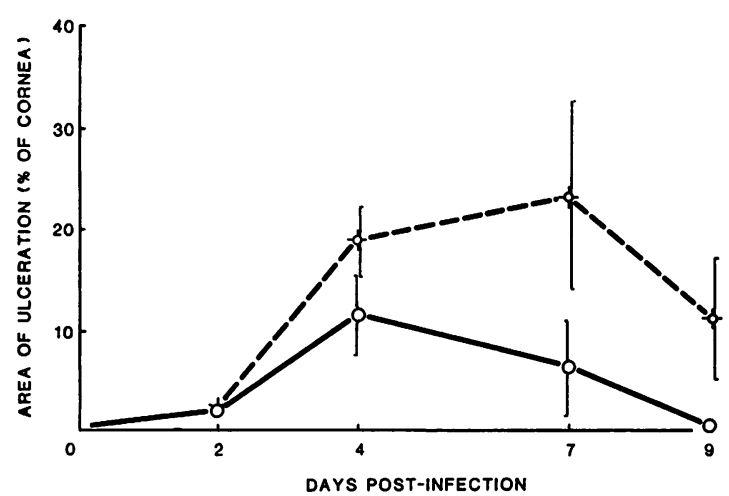

Fig. 3 Progress of ulcerative disease in placebo-

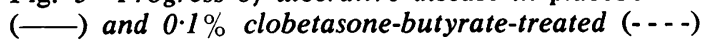
corneae: immunised rabbits (mean area of ulceration $\pm S E)$. Range of virus concentrations inoculated: 3.9 to $250.0 \times 10^{5} \mathrm{PFU} / \mathrm{ml}$.

EFFECTS OF $0.01 \%$ and $0.001 \%$ CLOBETASONE BUTYRATE IN IMMUNISED RABBITS

No differences in CID $_{50}$ were observed between eyes treated with placebo and with $0.01 \%$ or $0.001 \%$ clobetasone butyrate (Table 1 ).

The exacerbating effect of $0.01 \%$ clobetasone butyrate on ulcerative disease was clearly less than that of the $0.1 \%$ preparation. An increase in area of corneal ulceration in the $0.01 \%$ clobetasone-butyrate- compared with the placebotreated eye was seen in 2 of 5 rabbits on day 4 and in 3 of the 4 remaining animals on day 7 (Fig. 4).
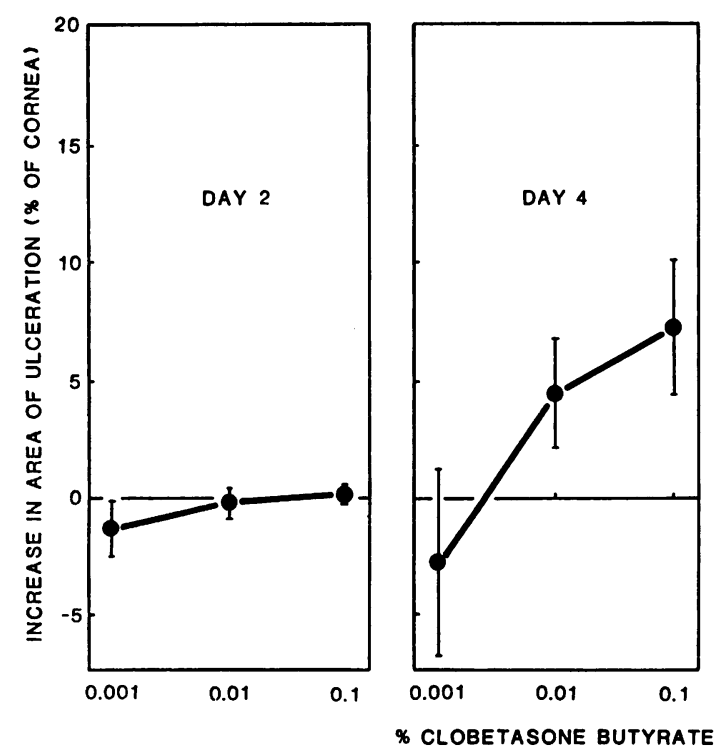

Treatment with $0.001 \%$ clobetasone butyrate had no discernible effect on the extent of ulceration at any stage of the infection (Fig. 4).

\section{Discussion}

It may be concluded that clobetasone butyrate nas no effect on initial corneal susceptibility to infection; it produces a considerably greater exacerbation of ulceration in immunised than in normal rabbits; this exacerbation is apparent late in the infection (and delays the initiation of healing); and it is dose-dependent.

The lack of any significant effect in normal animals is at variance with the findings of previous studies, ${ }^{3-6}$ and it might be related to the steroid and schedule used or to the termination of this experiment before the beginning of the healing phase. ${ }^{8}$ However, it is clear that a much greater enhancement of ulceration occurred in immunised rabbits, and an experimental model employing animals with previous skin or ocular HSV infection provides a close parallel with human disease. 811

In immunised rabbits a gradation in effect was observed from a distinct exacerbation of ulceration with $0.1 \%$ clobetasone butyrate to an indiscernible effect with the $0.001 \%$ preparation, indicating that the maximum 'safe' concentration in this model lies between 0.01 and $0.001 \%$. Various dilutions of corticosteroid are now used clinically, ${ }^{2}$ and an understanding of the effects of low concentrations on ulcerative herpetic

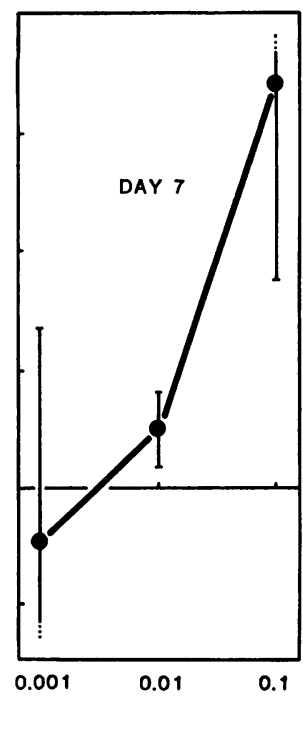

Fig. 4 Dose response curves for the exacerbating effect of clobetasone butyrate on ulcerative herpetic keratitis in immunised rabbits (mean increase in area of ulceration in corticosteroid-compared with placebo-treated eyes $\pm S E$ ). 
keratitis could help to decide when antiviral cover is necessary and to select moderate concentrations for general use. It is conceivable that a low concentration of corticosteroid could carry anti-inflammatory activity without risk of enhancement of herpetic disease, since the doseresponse relationships are probably different for the 2 effects. ${ }^{12}$

We are grateful for the help and encouragement of Professor J. H. Peacock and Dr M. O. Symes. This work was kindly supported by a Research to Prevent Blindness grant from the RNIB.

\section{References}

1 Thygeson P, Hogan MJ, Kimura SJ. The unfavourable effect of topical steroid therapy on herpetic keratitis. Trans Am Ophthalmol Soc 1960; 58:245-57.

2 Williams HP, Falcon MG, Jones BR. Corticosteroids in the management of herpetic eye disease. Trans Ophthalmol Soc UK 1977; 97:341-4.

3 Jawetz E, Okumoto M, Sonne M. Studies on herpes simplex $X$. The effect of corticosteroids on herpetic keratitis in the rabbit. J Immunol 1959; 83:486-90.

4 McCoy GA, Leopold IH. Steroid treatment of herpes simplex infections of the cornea. Am J Ophthalmol 1960; 49:1355-6.

5 Kimura SJ, Diaz-Bonnet V, Okumoto M, Hogan MJ. The effects of corticosteroid hormones on experimental herpes simplex keratitis. A clinical, histopathologic and histochemical study. Am J Ophthalmol 1961; 51:945-8.

$6 \mathrm{Oh}$ JO. Enhancement of virus multiplication and interferon production by cortisone in ocular herpes virus infection. J Immunol 1970; 104:1359-63.

7 Berenbaum MC. Comparison of the mechanisms of action of immunosuppressive agents. Prog Immunol 1974; 5:233-43.

8 Carter CA, Easty DL. Experimental ulcerative herpetic keratitis I. Systemic immune responses and resistance to corneal infection. Br J Ophthalmol 1981; 65:77-81.

9 Dunne JA, Travers JP. Double blind clinical trial of topical steroids in anterior uveitis. $\mathrm{Br} J$ Ophthalmol $1979 ; 63: 762-7$.

10 Ramsell TG, Bartholomew RS, Walker SR. Clinical evaluation of clobetasone butyrate: a comparative study of its effects in postoperative inflammation and on intraocular pressure. Br J Ophthalmol 1980; 64:42-5.

11 Easterbrook M, Wilkie J, Coleman V, Dawson CR. The effect of topical corticosteroids on the susceptibility of immune animals to reinoculation with Herpes Simplex. Invest Ophthalmol Visual Sci 1973; 12:181-4.

12 Kaufman HE. Topical corticosteroids: dose response relationship. In: Leopold IH, Ed. Ocular Therapy. St Louis: Mosby, 1978; 3:106. 